\title{
Respiration and the carbon-to-nitrogen ratio of a phytoplankton bloom
}

\author{
P. E. Kepkay ${ }^{1, *}$, J. F. Jellett ${ }^{3}$, S. E. H. Niven ${ }^{2}$ \\ ${ }^{1}$ Biological Oceanography Section, Ocean Sciences Division, and ${ }^{2}$ Marine Chemistry Section, Marine Environmental \\ Sciences Division, Fisheries and Oceans Canada, Bedford Institute of Oceanography, PO Box 1006, Dartmouth, Nova Scotia, \\ Canada B2Y 4A2 \\ ${ }^{3}$ Jellett Biotek, 101 Research Drive, PO Box 790, Dartmouth, Nova Scotia, Canada B2Y $3 Z 7$
}

\begin{abstract}
During the 1995 spring bloom in Bedford Basin, Nova Scotia, Canada, dissolved organic carbon (DOC) and nitrogen (DON) in surface waters were separated by cross-flow ultrafiltration into low molecular weight and colloidal size fractions. In order to obtain realistic estimates of the total standing stock of organic carbon and nitrogen during the bloom, measurements of DOC and DON in the ultrafiltered size fractions were combined with particulate organic carbon (POC) and nitrogen (PON) measurements. The combined C:N ratio of the total standing stock of organic matter (TOM) mcreased from near-Redfield values to a maximum during the early bloom as carbon-rich diatom exudates accumulated in the dissolved (primarily the collordal) size fraction. Even though the colloidal exudates were only a small frection $(<12 \%)$ of the TOM, they had a pronounced effect on the C:N ratio. In distinct contrast, the C:N of particulate organic matter (POM) remained almost invariant, contributing little to the change in the combined C:N ratio. Respiration was closely associated with the C:N of TOM and colloidal organic matter (COM), but appeared to have little effect on one of the most commonly utilized indices of ocean productivity - the C:N of POM. Instead, by the end of the bloom, respiration had returned the $C: N$ ratio of the TOM to near-Redfield values by selectively degrading the colloidal and low molecular weight organic carbon associated with the production of diatom exudates.
\end{abstract}

KEY WORDS: Microbial respiration · Coastal bloom $\cdot$ C:N ratio

\section{INTRODUCTION}

Dissolved organic carbon (DOC) is the largest reservoir of organic carbon in the ocean, outweighing detritus and 'living' carbon (phytoplankton, bacteria and zooplankton biomass) by a considerable margin (Kepkay 1994 and references therein). Smith \& Hollibaugh (1993) have suggested that the degradation of particulate organic carbon (POC) to form DOC, and the longterm oxidation of DOC by respiration are key processes in the transport of carbon between coastal and open oceans. The coastal zone is a net heterotrophic system (Smith \& Mackenzie 1987), where respiration must exceed primary production to break down the additional input of organic carbon. from terrestrial

•E-mail:p_kepkay@bionet.bio.dfo.ca sources. The slow oxidation of DOC as it is transported offshore is required to maintain an open-ocean system where respiration is slightly in excess of primary production (Smith \& Hollibaugh 1993).

The magnitude and rate of offshore DOC transport are regulated by a combination of physical and biological processes, including: (1) the coagulation of colloids (i.e. particles and aggregates between $1 \mathrm{~nm}$ and a few $\mu \mathrm{m}$ in diameter) into larger aggregates (Kepkay 1994 and references therein); (2) the vertical mixing of DOC and aggregates between surface and deep water (Carlson et al. 1994); (3) the respiratory degradation of colloidal fractions of DOC (Amon \& Benner 1994) and aggregates of larger colloids (Kepkay 1994 and references therein).

Given the importance of respiration in the regulation of the ocean carbon balance (Smith \& Hollibaugh 1993), there is a surprising absence of direct measurements - 
especially of respiration in association with a complete organic carbon inventory that takes both dissolved and particulate fractions into account. Added to this, there have only been a few reports (e.g. by Smith et al. 1991) that highlight the combined effect of primary production and organic carbon degradation on the nutritional quality (i.e. the phosphorus and/or nitrogen content) of marine organic matter. In response, we report here how respiration is related to the carbon-to-nitrogen $(\mathrm{C}: \mathrm{N})$ ratio of particulate and dissolved size fractions during a coastal diatom bloom.

\section{MATERIAL AND METHODS}

Sampling. Seawater was collected from depths of 5 and $15 \mathrm{~m}$ at a site located in $40 \mathrm{~m}$ of water in Bedford Basin, Nova Scotia, Canada. Samples were taken at weekly intervals from February 15 to May 3, 1995, to monitor the development and decline of the spring phytoplankton bloom. The Basin is a small. (17 $\left.\mathrm{km}^{2}\right)$ coastal bay connected to the North Atlantic Occan by Halifax Harbour. Estuarine circulation in the Basin is driven by tides that exchange $4.9 \%$ of a total volume of $516 \times 10^{6} \mathrm{~m}^{3}$ (Gregory et al. 1993) and by freshwater input dispersed by the wind field (Petrie \& Yeats 1990). The main source of freshwater is the Sackville River (which had an average annual inflow of $4.8 \mathrm{~m}^{3} \mathrm{~s}^{-1}$ from March 1, 1994, to March 1, 1995) and the salinity of surface waters can range from 28 to 32 (Petrie \& Yeats 1990)

Peristaltic pumps, equipped with acid-cleaned silicone tubing, were used to draw seawater from both depths through acid-cleaned Kynar tubing. Samples of unfiltered seawater were taken for respiration measurements and for the analysis of bulk chlorophyll a (chl a), nutrients and particulates. Seawater was also collected for ultrafiltration and analysis of dissolved $(<0.2 \mu \mathrm{m}$ ) organic carbon (DOC) and nitrogen (DON) by pumping through $0.2 \mu \mathrm{m}$ Gelman Minicapsule cartridge filters attached to the outlets of the peristaltic pumps. The filters were precleaned by flushing with $005 \mathrm{M} \mathrm{HCl}$ followed by deionized water (Millipore Super- $(2)$ and rinsed with several liters of seawater before samples were collected. Filters were changed during sampling when a significant decrease in flow rate was observed.

DOC samples $(50$ to $80 \mathrm{ml})$ were collected in $250 \mathrm{ml}$ fluorinated polyethylene bottles (Nalgene) that had been soaked overnight in $10 \% \mathrm{HCl}(\mathrm{v} / \mathrm{v})$, rinsed 5 times in distilled water and oven-dried at $80^{\circ} \mathrm{C}$. DON samples $(20$ to $30 \mathrm{ml}$ ) were collected in $60 \mathrm{ml}$ glass screw-cap tubes that had been precombusted at $550^{\circ} \mathrm{C}$ for $4 \mathrm{~h}$. Prior to filling, the bottles and tubes were rinsed with filtured seawater from the appropriate depth. DOC samples were then stored at $5^{\circ} \mathrm{C}$ in the dark and analyzed within $2 \mathrm{~d}$ of collection; DON samples were frozen and analyzed within $30 \mathrm{~d}$ of collection. The filtered seawater obtained for ultrafiltration was transported to the laboratory in $20 \mathrm{l}$ acid-cleaned polyethylene jerricans.

Hydrography, chl a, nutrients and particulates. Water temperature, salinity and fluorescence were monitored as continuous profiles by a Seabird Model 25 CTD. The fluorometer was calibrated with discrete chl a samples collected for analysis on Whatman GF/F filters and measured by a standard fluorometric method based on that of Holm-Hansen et al. (1965). Inorganic nutrients (nitrate, phosphate and silicate) were measured by standard methods using a Technicon autoanalyzer; ammonium was analyzed using an automated method adapted from Grasshoff \& Johannsen (1972). Particulate organic carbon (POC) and nitrogen (PON) were determined by high temperature combustion (in a Perkin Elmer 2400 CHN analyzer) of samples concentrated onto GF/F filters that had been precombusted at $450^{\circ} \mathrm{C}$ for $2 \mathrm{~h}$. Data on discharge of the Sackville River were provided by the Water Resources Branch of Environment Canada.

Cross-flow ultrafiltration. Millipore cross-flow ultrafiltration systems (each equipped with 2 Millipore PLGC Prep/Scale-TFF-6 cartridges connected in parallel) were used to collect and concentrate colloidal material from the $0.2 \mu \mathrm{m}$ prefiltered samples; 2 separate ultrafiltration systems were used for the 5 and $15 \mathrm{~m}$ sampling depths. The PLGC Prep/Scale cartridge is a 10000 nominal molecular weight (NMW) or $10 \mathrm{kD}$ filter with a $0.7 \mathrm{~m}^{2}$ regenerated-cellulose membrane and retains material greater than about 1 to $2 \mathrm{~nm}$ in diameter. As a result, the term 'dissolved' was applied to the material passing through the $0.2 \mu \mathrm{m}$ prefilter. The term 'colloidal' was applied to material between. 1 to $2 \mathrm{~nm}$ and $0.2 \mu \mathrm{m}$ in diameter, and 'low molecular weight' was applied to material passing through the Prep/Scale filter (i.e. with a nominal diameter of $<1$ to $2 \mathrm{~nm}$ ). A $10000 \mathrm{NMW}$ cartridge was employed rather than the more common $1000 \mathrm{NMW}$ (or $1 \mathrm{kD}$ ) cutoff (Buesseler et al. 1997) to minimize the time required to process large samples. The flow rates of 25 to $30 \mathrm{l} \mathrm{h}^{-1}$ employed with the high-volume peristaltic pumps connected to our systems allowed the separation of 100 to 1.501 of prefiltered seawater into colloidal and low molecular weight size fractions within $5 \mathrm{~h}$.

Each ultrafiltration system was cleaned and conditioned by leaching with $0.1 \mathrm{M} \mathrm{HCl}$ for at least $12 \mathrm{~h}$, flushing with $30 \mathrm{I}$ of $0.2 \mu \mathrm{m}$ filtered, distilled, deionized water (Millipore Super-Q), circulating $0.1 \mathrm{M} \mathrm{NaOH}$ for at least 30 min and flushing with an additional 30 l of the deionized water. The complete system was then soaked for at least $4 \mathrm{~h}$ with seawater that had previ- 
ously been ultrafiltered to reduce the adsorptive loss of DOC onto tubing and ultrafiltration membranes during sample processing. The $0.2 \mu \mathrm{m}$ prefiltered seawater from each sampling depth was combined in a 200 l tank and transferred by peristaltic pump to an 81 polypropylene bottle used as a retentate reservoir Both the tank and reservoir had been acid-cleaned and rinsed with deionized water prior to use. During ultrafiltration, seawater was pumped from the reservoir to the inlet of the ultrafiltration cartridges and the retentate recirculated to the reservoir to be collected as the colloidal size fraction; the permeate (ultrafiltrate) was collected in a separate acid-cleaned container. The retentate was continually replenished with filtered seawater from the $200 \mathrm{l}$ tank so that the volume of water in the reservoir was maintained at between 4 and 61 .

At the beginning of each ultrafiltration run, two 51 aliquots of the prefiltered seawater were circulated through the system and discarded. The remainder was ultrafiltered under pressures of 18 to $20 \mathrm{psi}$ (124 to $138 \mathrm{kPa}$ ), resulting in the separation of low molecular weight and colloidal material and the concentration of colloidal material in the retentate. Pump speed was adjusted and the retentate line was restricted slightly to achieve a constant flow of 25 to $30 \mathrm{l}$ of permeate $\mathrm{h}^{-1}$ and a recirculation flow that was between 6 and 10 times the permeate flow.

When approximately 401 of sample had passed through the ultrafiltration membrane, the permeate was sampled for the analysis of low molecular weight organic carbon and nitrogen (LOC and LON). Prior to sampling, the intake line was transferred from the retentate reservoir to the $200 \mathrm{l}$ tank so that filtration artifacts (Buesseler et al. 1997) created by membrane breakthrough (related to the buildup of colloidal concentrate in the retentate reservoir) were minimized. Once the sample for LOC(N) analysis was collected, the inlet was returned to the retentate reservoir and ultrafiltration was continued until the volume of retentate (colloid concentrate) was between 1 and 21 (equivalent to a concentration factor of 55 to 86 ). The retentate outlet was then opened and the permeate outlet closed, allowing the retentate to be circulated at a pressure of 10 psi $(69 \mathrm{kPa}$ ) for $10 \mathrm{~min}$ (to minimize adhesion of colloids to the membrane). The retentate was then sampled for the analysis of colloidal organic carbon and nitrogen (COC and CON).

In addition to organic carbon and nitrogen, ${ }^{234} \mathrm{Th}$ was measured in samples from both the retentate and the ultrafiltrate; the ${ }^{234}$ Th results are reported elsewhere (Niven et al. 1997). The COC and CON concentration in each retentate $\left[\mathrm{COC}(N)_{\text {ret }}\right]$ was corrected for the concentration of $\operatorname{LOC}(\mathrm{N})$ and for the reduction in retentate volume during ultrafiltration (Kepkay et al.
1993, 1997, Niven et al. 1995). Mass balances were calculated as the sum of $\operatorname{LOC}(\mathrm{N})$ and $\operatorname{COC}(\mathrm{N})_{\text {rel, }}$ and expressed as percent of the dissolved $(<0.2 \mu \mathrm{m})$ fraction. The organic carbon mass balances were generally $>92 \%$ (Kepkay et al. 1997); the organic nitrogen mass balances were $>95 \%$

DOC. Acidified samples of the dissolved, colloidal and low molecular weight fractions were analyzed for their organic carbon content by high temperature catalytic oxidation as described in detail by Kepkay et al. $(1993,1997)$. The concentration of organic carbon in each sample was determined from standard curves generated from the analysis of glucose in fresh distilled water. Typical standard deviations of individual standard and sample analyses were $\leq 2.6 \mu \mathrm{M} \mathrm{C}$ and the analytical blank was 15 to $20 \mu \mathrm{M} \mathrm{C}$. When the contribution of the distilled water $(<10 \mu \mathrm{M}$ C, as measured by Chen \& Wangersky 1993 ) to the analytical blank was taken into account, the residual instrument blank was between 5 and $10 \mu \mathrm{M} \mathrm{C}$ - similar to values obtained by Tupas et al. (1994). The instrument blank was subtracted from all our measurements.

DON. The high temperature catalytic oxidation instrument of Chen \& Wangersky (1993) was adapted for the colorimetric determination of oxidized nitrogen and used to analyse samples for the total nitrogen content of the dissolved, colloidal and low molecular weight fractions. Typical standard deviations of sample analyses were $\leq 0.3 \mu \mathrm{M} \mathrm{N}$; the analytical blank was 2.8 to $3.0 \mu \mathrm{M} \mathrm{N}$ and the instrument blank was $<0.2 \mu \mathrm{MN}$. DON, CON and LON were calculated by subtracting the combined total of nitrate and ammonium (dissolved inorganic nitrogen, DIN) from total nitrogen measurements.

Respiration. A pulsed oxygen electrode system (Endeco T.1125) adapted to a 16-electrode multiplexer was used to measure short-term, whole-community respiration following the procedures developed by J. F. Jellett, P. E. Kepkay, S. F. Malcolm, P. M. Dickie \& W. K. W Li (unpubl.). Unfiltered seawater from each of the 2 sampling depths was added to a 11,4 -electrode manifold and maintained at in situ temperature $\left(1\right.$ to $\left.3^{\circ} \mathrm{C}\right)$ in the dark. Once the electrodes had passed through a $45 \mathrm{~min}$ stabilization period, oxygen consumption in each of the 2 manifolds was monitored as decreasing signals obtained from 4 electrodes over an additional 30 min. As a result, the total incubation time required to obtain measurable respiration rates was $75 \mathrm{~min}$.

Electrode signals from the incubations were converted to oxygen concentrations (and respiration rate) using calibration data obtained from the same manifolds containing filter $(0.2 \mu \mathrm{m})$-sterilized seawater that was sequentially sparged with 3 different analyzed gas mixtures of oxygen and nitrogen. Electrode drift was accounted for as blank corrections that were obtained 
using non-sparged, filter-sterilized seawater; these blank values were subtracted from all the respiration measurements in untreated seawater.

\section{RESULTS}

\section{Onset and decline of the bloom}

On March 15 (Day 74), the onset of the spring bloom at $5 \mathrm{~m}$ was signalled by an increase of chl a above prebloom concentrations of 1 to $2 \mu \mathrm{g} \mathrm{I}^{-1}$ (Fig. 1A). Two weeks later (on March 29 or Day 88), chl a had reached
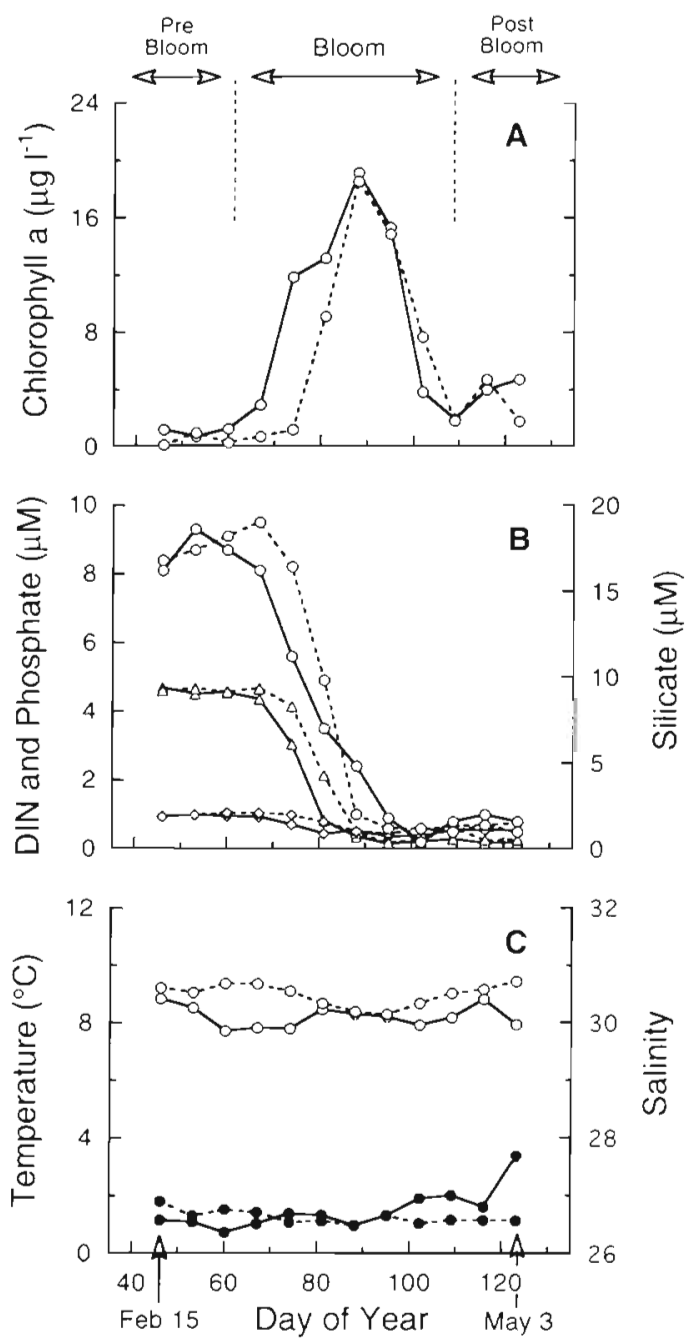

Fig. 1. Bulk chlorophyll a (chl a), nutrients, temperature and salinity at depths of $5 \mathrm{~m}$ (solid line) and $15 \mathrm{~m}$ (broken line) during the pre-bloom, bloom and post-bloom. (A) Bulk chl $a_{i}$ $(B)$ dissolved inorganic nitrogen $(O)$, silicate $(\Delta)$ and phosphate $(0)$; $(C)$ temperature $(\bullet)$ and salinity $(O)$ of a stable, poorly stratified water column. The duration of the bloom was defined as sample intervals where chl a exceeded an arbitrary background concentration of 1 to $4 \mu \mathrm{gl}^{-1}$ a maximum of $19.1 \mathrm{\mu g} \mathrm{l}^{-1}$, and then declined to postbloom concentrations of 2 to $6 \mu \mathrm{g} \mathrm{I}^{-1}$ by April 19 (Day 109) The bloom at $15 \mathrm{~m}$ began 1 wk later (Fig. 1A), reaching a similar maximum in chl a by Day 88 , and declined to post-bloom concentrations by Day 109. At both depths, dissolved inorganic nitrogen (the combined total for nitrate and ammonium), silicate and phosphate reached low $(\sim 1 \mu \mathrm{M})$ concentrations near the end of the bloom (Fig. 1B); salinity remained moreor-less constant at 30 to 31 throughout the bloom, and temperature remained low at 1 to $3^{\circ} \mathrm{C}$ (Fig. $1 \mathrm{C}$ ).

The hydrographic characteristic of this bloom that distinguished it from previous studies in Bedford Basin (Kepkay et al. 1993, Niven et al. 1995) was the weak stratification of the water column (Fig. 1C). During previous blooms, precipitation was relatively high so that discharge of the Sackville River reached values of up to $20 \mathrm{~m}^{3} \mathrm{~s}^{-1}$ (Kepkay et al. 1993, Niven et al. 1995). In contrast, the average discharge for the Sackville River during the 1995 bloom was $5.1 \mathrm{~m}^{3} \mathrm{~s}^{-1}$ - only slightly higher than an annual average of $4.8 \mathrm{~m}^{3} \mathrm{~s}^{-1}$ As a result, both temperature and salinity remained uniform with depth (Fig. 1C Kepkay et al. 1997) and there appeared to be an overall lack of extensive vertical mixing. This allowed the chlorophyll maximum to develop down to depths of about $20 \mathrm{~m}$ by Day 88 - the height of the bloom (as defined by chl a measurements). By the time the post-bloom had arrived (Day 109), some stratification had developed in the upper $5 \mathrm{~m}$, but chl a had returned to relatively uniform and low concentrations over the entire $40 \mathrm{~m}$ of the water column (Kepkay et al. 1997).

\section{Size fractionation of organic carbon and nitrogen}

Traditionally, total standing stocks of organic carbon (TOC) and nitrogen (TON) in seawater have been subdivided into particulate and dissolved size fractions. We followed this approach by including material greater than $0.4 \mu \mathrm{m}$ in diameter (the nominal pore size of a Whatman GFF filter) in the particulate fraction and material less than $0.2 \mu \mathrm{m}$ in diameter (the nominal pore size of the Gelman cartridge used to pretreat seawater before ultrafiltration) in the dissolved fraction. To pinpoint the biological reactivity of dissolved material, we subdivided the prefiltered seawater into a low molecular weight size fraction, which included material that was less than a nominal molecular weight of $10 \mathrm{kD}$ (or a nominal particle diameter of 1 to $2 \mathrm{~nm}$ ), and a colloidal size fraction (which was equivalent to a particle diameter of between $1 \mathrm{~nm}$ and $0.2 \mu \mathrm{m}$ ).

During the bloom at $5 \mathrm{~m}$, the TOC increased from about 95 to $159.8 \mu \mathrm{M} \mathrm{C}$ by Day 81 (Fig. 2A). This TOC maximum (which included the combined contributions 

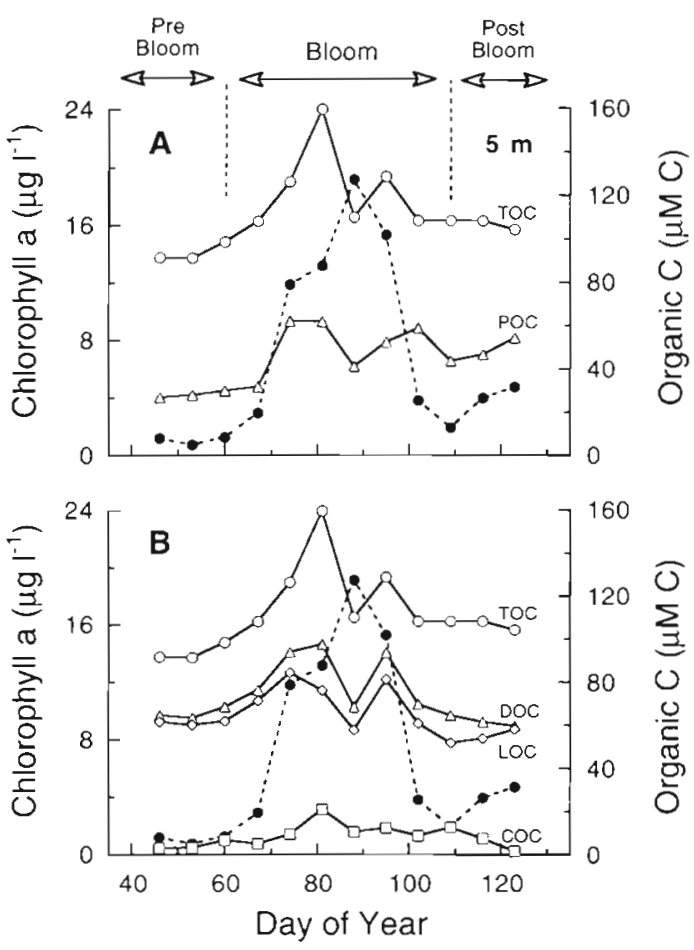

Fig. 2. (A) Total organic carbon (TOC) and particulate organic carbon (POC) during the bloom at $5 \mathrm{~m}$. (B) Dissolved organic carbon (DOC), low molecular weight organic carbon (LOC) and colloidal organic carbon (COC) plotted on the same scale as TOC. (...) Bulk chl a defines the duration of the bloom. The precision of DOC, LOC and COC measurements was $2.6 \mu \mathrm{MC}(1 \mathrm{~s})$; the precision of POC measurements was $3.2 \mu \mathrm{MC}(1 \mathrm{~s})$

of the particulate and dissolved size fractions) was 1 wk before the maximum in chl a and was followed by a smaller peak $1 \mathrm{wk}$ after the chl a maximum (Fig. 2A). TOC then declined to post-bloom concentrations of $108 \mu \mathrm{M}$ C. Particulate organic carbon (POC) also peaked at the same time as the TOC peaks, but was typically between 30 and $40 \%$ of TOC during the bloom (Fig. 2A). The remainder (and majority) of the TOC was found in the dissolved organic size fraction (DOC; Fig. 2B). Throughout the bloom, low molecular weight organic carbon (LOC; Fig. 2B) was the predominant component of this standing stock and colloidal organic carbon (COC; Fig. 2B) was no greater than $12 \%$ of TOC. Our measurements of DOC, LOC and COC were in agreement with data obtained from previous spring blooms (Kepkay et al. 1993, Niven et al. 1995) using a slightly different ultrafiltration system. Our measurements were also similar to values obtained from natural phytoplankton populations in estuaries (Samuel et al. 1971. Thomas 1971) and a natural phytoplankton bloom enclosed in an experimental mesocosm (Norrman et al. 1995). However, our measurements did not agree with the mesocosm results of
Smith et al. (1995), where a nutritionally induced diatom bloom yielded consistently more POC than DOC

In contrast to TOC, the TON at $5 \mathrm{~m}$ exhibited no discernible trends, and varied between 7.1 and $11.9 \mu \mathrm{MN}$ (Fig. 3). Particulate organic nitrogen (PON) was typically less than $40 \%$ of TON (Fig. 3A) and colloidal organic nitrogen (CON) remained at less than $1.4 \mu \mathrm{M}$ $N$ (or less than $9 \%$ of TON) throughout the bloom (Fig. 3B). The majority of the TON was in the low molecular weight size fraction (LON; Fig. 3B). Our measurements of dissolved organic nitrogen (DON; Fig. 3B) were in agreement with the range of values
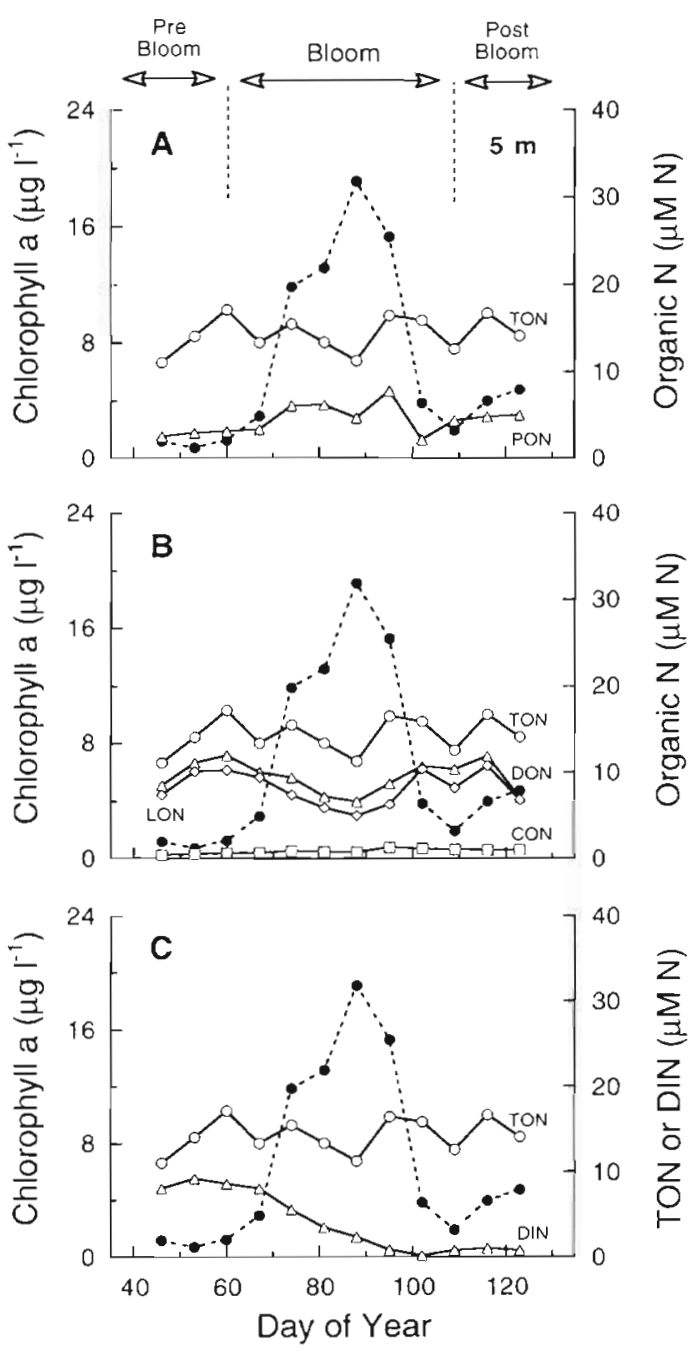

Fig. 3. (A) Total organic nitrogen (TON) and particulate orgamic nitrogen (PON) during the bloom at $5 \mathrm{~m}$. (B) Dissolved organic nitrogen (DON), low molecular weight organic nitrogen (LON) and colloidal organic nitrogen (CON) plotted on the same scale as TON. (C) Dissolved inorganic nitrogen (DIN), i.e. the combined total of ammonium and nitrate, is also plotted on the same scale as TON for reference. (-.--.) Bulk chl a defines the duration of the bloom. The precision of DON, LON, CON measurements was $0.3 \mu \mathrm{MN}(1 \mathrm{~s})$; the precision of PON measurements was $0.6 \mu \mathrm{MN}(1 \mathrm{~s})$ 
first established by Duursma (1961) and later confirmed by Walsh (1989), Karl et al. (1993), Hansell (1993) and Koike \& Tupas (1993) in the open ocean, and by Hansell (1993) and Hansell et al. (1993) in coastal waters. At $15 \mathrm{~m}$, the distributions of TOC, TON and size-fractionated organic carbon and nitrogen (Tables 1 \& 2) were similar to the results from $5 \mathrm{~m}$. However, the overall increase in DOC was smaller at the greater depth (Kepkay et al. 1997).

\section{Size-fractionated C:N ratio}

Prior to the bloom at $5 \mathrm{~m}$, the $\mathrm{C}: \mathrm{N}$ ratio of total organic matter (TOM) was between 6:1 and 7:1 (Fig. 4A) - close to the value of $6.7: 1$ proposed by Redfield et al. (1963) for the production and degradation of marine organic matter. During the bloom, the C:N ratio reached $11.9: 1$ by Day 81 (Fig. 4A) and then decreased to post-bloom values that were, again, close to the Redfield ratio (Fig. 4A). At $15 \mathrm{~m}$, there was a similar increase in the C:N of TOM (Fig. 4A), but a maximum of only 8.6:1 was reached by Day 81 - considerably less than the $C: N$ peak reached at $5 \mathrm{~m}$. At its maximum, the C:N of TOM at both depths was similar to cellular $C: N$ ratios measured by several authors during

Table 1 Total (TOC), particulate (POC), dissolved (DOC), low molecular weight (LOC) and colloidal (COC) organic carbon concentrations $(\mu \mathrm{M} C$ ) during the pre-bloom, bloom (Days 74 to 102) and post-bloom at $1.5 \mathrm{~m}$. The precision of DOC, LOC and $\mathrm{COC}$ measurements was $\leq 2.6 \mu \mathrm{MC}(1 \sigma)$ : the precision of POC measurements was $\leq 3.2 \mu \mathrm{M} C$ (1 $\sigma$ )

\begin{tabular}{|c|c|c|c|c|c|}
\hline Day of year & TOC $^{\mathrm{a}}$ & $\mathrm{POC}$ & $\mathrm{DOC}^{\mathrm{b}}$ & $\mathrm{LOC}^{\mathrm{c}}$ & $\operatorname{COC}^{d}$ \\
\hline $46^{\circ}$ & 74.1 & 12.1 & 62.0 & 61.0 & 1.0 \\
\hline 53 & 79.2 & 21.7 & 57.5 & 56.2 & 1.3 \\
\hline 60 & 79.0 & 20.7 & 58.3 & 55.8 & 2.5 \\
\hline 67 & 75.0 & 12.0 & 63.0 & 61.5 & 1.5 \\
\hline 74 & 89.3 & 18.8 & 75.2 & 73.6 & 1.6 \\
\hline 81 & 94.0 & 20.9 & 68.4 & 56.0 & 12.4 \\
\hline 88 & 131.3 & 37.6 & 93.7 & 86.6 & 7.1 \\
\hline 95 & 151.5 & 53.6 & 97.9 & 89.6 & 8.3 \\
\hline 102 & 111.3 & 39.1 & 72.2 & 66.1 & 6.1 \\
\hline 109 & 111.0 & 39.3 & 71.7 & 66.4 & 5.3 \\
\hline 116 & 95.7 & 26.1 & 69.6 & 66.5 & 3.1 \\
\hline $123^{f}$ & 93.1 & 34.6 & 58.5 & 56.5 & 2.0 \\
\hline \multicolumn{6}{|c|}{$\begin{array}{l}\text { 'Organıc carbon that passes through a precleaned } 0.2 \mu \mathrm{m} \\
\text { cartridge filter }\end{array}$} \\
\hline \multirow{2}{*}{\multicolumn{6}{|c|}{$\begin{array}{l}\text { 'Organic carbon that passes through the membranes in } \\
\text { precleaned cross-flow, ultrafiltration cartridges with a } \\
\text { nominal molecular weight cut-off of } 10 \mathrm{kD}(1 \text { to } 2 \mathrm{~nm}) \\
\text { dCalculated as the difference between } \mathrm{DOC} \text { and LOC } \\
\text { concentrations }\end{array}$}} \\
\hline & & & & & \\
\hline \multicolumn{6}{|c|}{${ }^{\mathrm{e}}$ February 15, 1995} \\
\hline \multicolumn{6}{|l|}{${ }^{\prime}$ May 3, 1995} \\
\hline
\end{tabular}

Table 2. Total (TON), particulate (PON), dissolved (DON), low molecular weight (LON) and colloidal (CON) organic nitrogen concentrations ( $\mu \mathrm{M} \mathrm{N})$ during the pre-bloom, bloom (Days 74 to 102) and post-bloom at $15 \mathrm{~m}$. The precision of DON, LON and CON measurements was $\leq 0.3 \mu \mathrm{MN}(1 \sigma)$ : the precision of PON measurements was $\leq 0.6 \mu \mathrm{MN}(1 \sigma)$

\begin{tabular}{|c|c|c|c|c|c|}
\hline Day of year & TON & PON & DON & LON & $\mathrm{CON}^{\mathrm{d}}$ \\
\hline $46^{\circ}$ & 9.3 & 1.1 & 8.2 & 6.4 & 1.8 \\
\hline 53 & 14.4 & 2.3 & 12.1 & 11.0 & 1.1 \\
\hline 60 & 12.8 & 2.0 & 10.8 & 9.8 & 1.0 \\
\hline 74 & 10.9 & 1.8 & 9.1 & 8.5 & 0.6 \\
\hline 81 & 13.6 & 2.3 & 11.3 & 10.0 & 1.3 \\
\hline 88 & 15.3 & 4.8 & 10.5 & 8.0 & 2.5 \\
\hline 95 & 18.8 & 8.2 & 10.6 & 8.7 & 1.9 \\
\hline 109 & 15.5 & 3.9 & 11.6 & 10.8 & 1.2 \\
\hline 116 & 16.2 & 2.9 & 13.4 & 13.3 & 0.1 \\
\hline $123^{i}$ & 13.3 & 2.9 & 10.4 & 9.8 & 0.6 \\
\hline \multicolumn{6}{|c|}{$\begin{array}{l}\text { "Organic nitrogen that passes through a precleaned } \\
0.2 \mu \mathrm{m} \text { cartridge filter }\end{array}$} \\
\hline \multicolumn{6}{|c|}{$\begin{array}{l}\text { 'Organic nitrogen that passes through the membranes in } \\
\text { precleaned cross-flow, ultrafiltration cartridges with a } \\
\text { nominal molecular weight cut-off of } 10 \mathrm{kD}(1 \text { to } 2 \mathrm{~mm}) \\
\text { dCalculated as the difference between DON and LON } \\
\text { concentrations } \\
\text { 'February } 15,1995 \\
\text { May 3,1995 }\end{array}$} \\
\hline
\end{tabular}

the growth of phytoplankton in culture (Dortch 1982 and references therein) and, more specifically, to the combined C:N ratio of dissolved (DOM) and particulate (POM) organic matter obtained by Biddanda \& Benner (1996) during the production of extracellular polysaccharides by diatoms in culture

In contrast to TOM, the $\mathrm{C}: \mathrm{N}$ ratio of POM remained relatively uniform at both 5 and $15 \mathrm{~m}$. The ratio varied from $7: 1$ to $9: 1$, which was well within the range obtained by several authors during the growth of phytoplankton in culture (Goldman et al. 1979 and references therein, Dortch 1982 and references therein), and exhibited no discernible trend (Fig. 4B). The dissolved, rather than the particulate, fraction of organic matter (Fig. 4C, D) appeared to be responsible for the change in $\mathrm{C}: \mathrm{N}$ of TOM and the colloidal size fraction underwent the largest change in $\mathrm{C}: \mathrm{N}$ ratio (Fig. $4 \mathrm{C}$ ). At both 5 and $15 \mathrm{~m}$, the $\mathrm{C}: \mathrm{N}$ of colloidal organic matter (COM) increased from values similar to the Redfield ratio (Fig. $4 \mathrm{C}$ ) to peaks of 20.5:1 (at $5 \mathrm{~m}$ ) and $9.9: 1$ (at $15 \mathrm{~m}$ ). The C:N of COM then decreased to post-bloom values that were, again, similar to the Redfield ratio (Fig. 4C).

The $\mathrm{C}: \mathrm{N}$ ratios of DOM and low molecular weight organic matter (LOM) were similar at both depths (Fig. 4D), increasing from values similar to the Redfield ratio to between 13.0:1 and 13.6:1 (at $5 \mathrm{~m}$ ) and 8.9:1 (at $15 \mathrm{~m}$ ), followed by a decrease to Redfield values by the post-bloom. The close agreement between $\mathrm{C}: \mathrm{N}$ ratios 

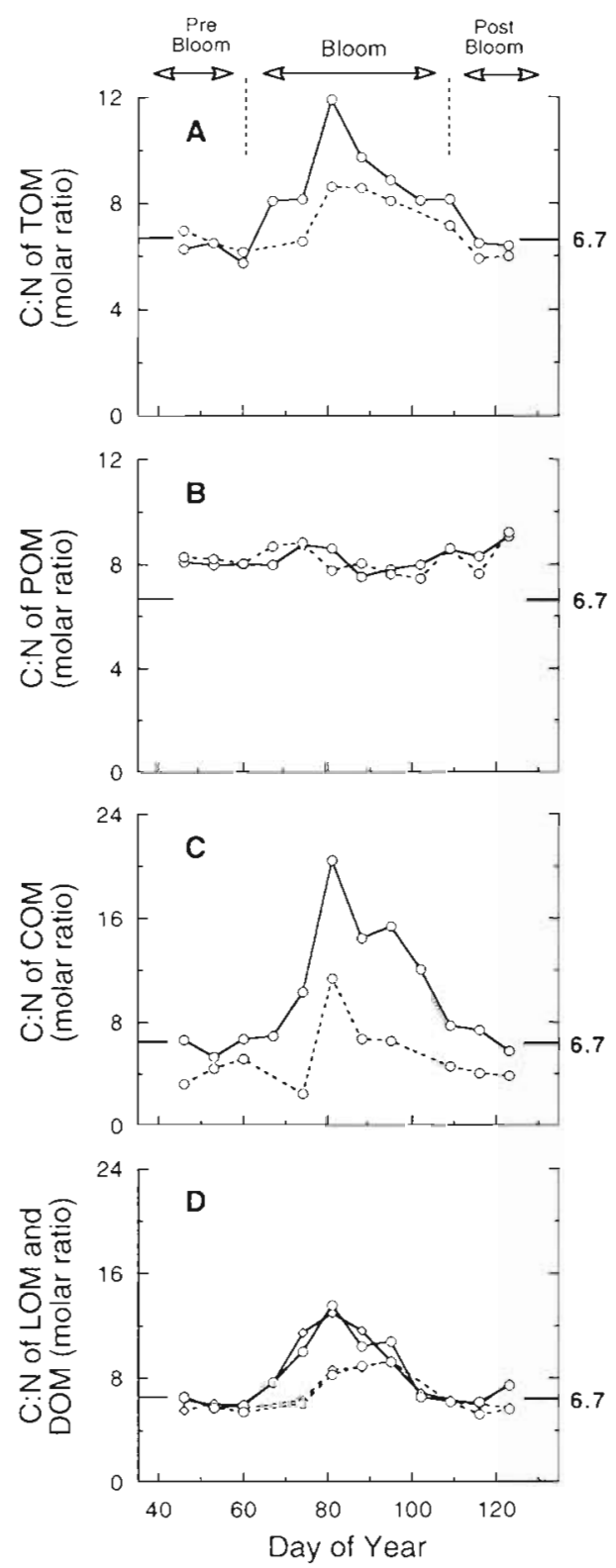

Fig. 4. C:N ratio of (A) total organic matter, (B) particulate organic matter, (C) colloidal organic matter and (D) dissolved (0) or low molecular weight (0) organic matter during the bloom at $5 \mathrm{~m}$ (solid line) and $15 \mathrm{~m}$ (broken line). The Redfield ratio $(6.7: 1)$ for the production and degradation of marine organic matter is shown for reference

of LOM and DOM at both depths probably reflects the predominant contribution of low molecular weight material to DOM during blooms (Kepkay et al. 1993, 1997. Niven et al. 1995). In addition, our range of $C: N$ ratios for size-fractionated DOM (Fig. 4C, D) was similar to values obtained by Biddanda \& Benner (1996) in culture, and at the low end of the range (18 to 33) established for coastal waters and the open ocean (Duursma 1961, Hansell 1993).
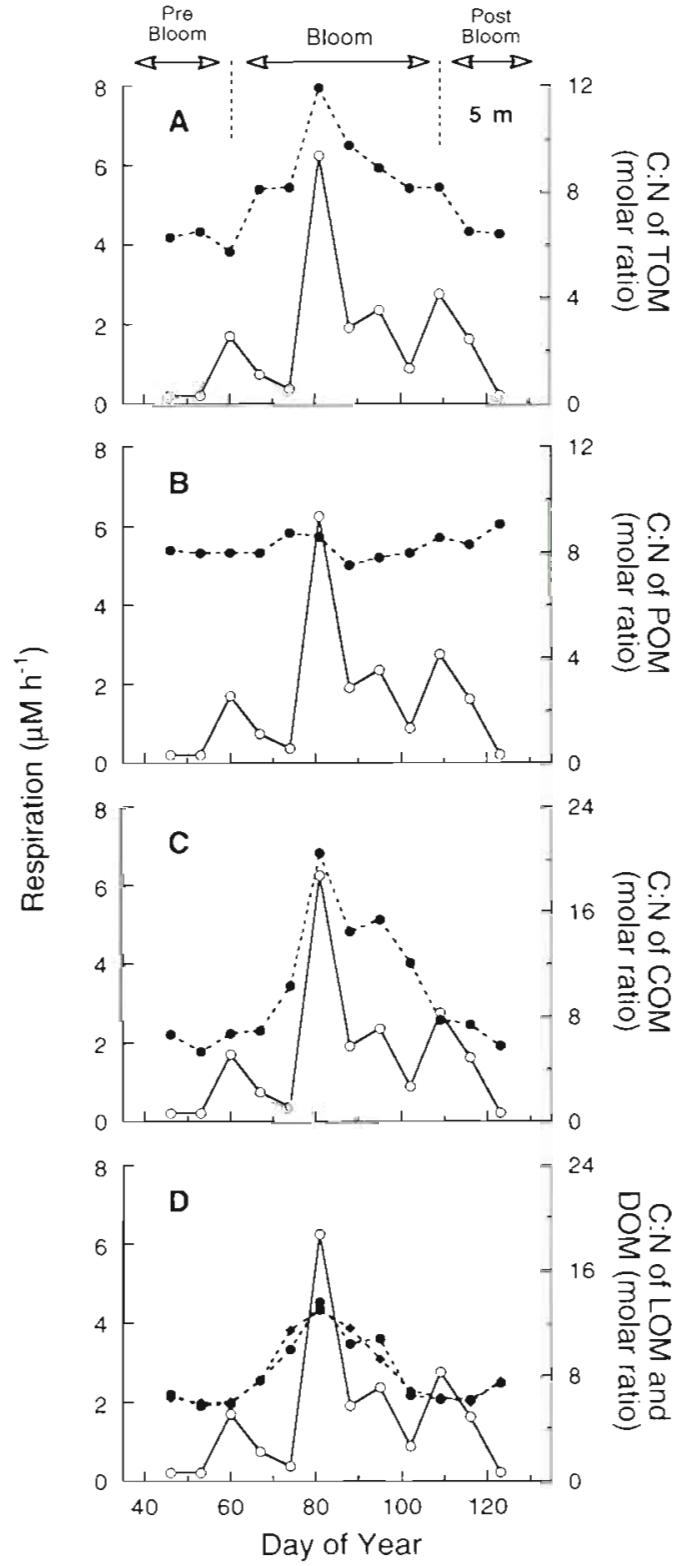

Fig. 5. Comparison of respiration (solid line) during the bloom at $5 \mathrm{~m}$ with the $\mathrm{C}: \mathrm{N}$ ratio (broken line) of (A) total organic matter, (B) particulate organic matter, (C) colloidal organic matter and (D) dissolved ( $\bullet$ ) or low molecular weight ( $\bullet$ organic matter. Pearson correlation coefficients ( $r$ ) of the variation of respiration with $\mathrm{C}: \mathrm{N}$ ratio are summarized in Table 3

\section{Respiration and the size-fractionated $\mathrm{C}: \mathrm{N}$ ratio}

During the bloom at $5 \mathrm{~m}$, respiration of the whole community and the C:N of TOM appeared to be closely associated (Fig. 5A), reaching coincident maxima by Day 81 . The 2 parameters were well correlated (Table 3), with a significant Pearson correlation coefficient ( $r)$ of $0.775(p \leq 0.003)$. In contrast, the C:N of POM did not reach a maximum by Day 81 (Fig. 5B) and 
Table 3. Correlation of respiration at $5 \mathrm{~m}$ with the $\mathrm{C}: \mathrm{N}$ of total organic material (TOM) and the C:N of organic material in the particulate (POM), colloidal (COM), dissolved (DOM) and low molecular weight (LOM) size fractions. Correlations are expressed in terms of the Pearson (linear) correlation coefficient ( $r$ ) and the significance ( $p$ ) associated with each correlation. For the sake of comparison, p 0.005 is strongly significant, $p$ between 0.005 and 0.100 is weakly significant and $p$ 0.100 is not significant

\begin{tabular}{|c|c|c|}
\hline $\begin{array}{l}\text { Organic carbon } \\
\text { size fraction }\end{array}$ & \multicolumn{2}{|c|}{$\begin{array}{l}\text { Correlation } \\
\text { coefficient }(r)\end{array}$} \\
\hline TOM & $0.775(p$ & $0.003)$ \\
\hline POM & $0.048(\mathrm{p}$ & 0.8821 \\
\hline COM & $0.802(p$ & $0.005)$ \\
\hline DOM & $0.542(p$ & $0.069\}$ \\
\hline LOM & $0.525(p$ & $0.120)$ \\
\hline
\end{tabular}

there was no significant correlation with respiration (Table 3). The correlation between respiration and the $\mathrm{C}: \mathrm{N}$ of TOM at $5 \mathrm{~m}$ (Table 3 ) appeared to be a function of the dissolved (rather than the particulate) component of TOM (Fig. 5). In particular, the colloid-sized fraction of TOM appeared to be the most closely associated with respiration at $5 \mathrm{~m}$ (Fig. 5C, Table 3). The Pearson correlation coefficient (r) for respiration and the C:N of COM was 0.802 ( $p \quad 0.005$ ), while the correlation coefficients of respiration with the C:N of LOM or DOM were either marginally significant or not significant (Table 3).

At $15 \mathrm{~m}$, respiration was less well correlated with the C:N of TOM (Fig. 6A, Table 4), primarily because the increase in C:N ratio during the bloom (Fig. 6A) was relatively small. The absence of a significant correlation of respiration with the C:N of POM (Fig. $6 B$, Table 4) was similar to the results from $5 \mathrm{~m}$ (Fig. 5B, Table 3 ) and there was a strong significant correlation ( $\mathrm{r}=0.972, \mathrm{p} \quad 0.005$ in Table 4 ) of respiration with the $\mathrm{C}: \mathrm{N}$ of COM (Fig. 6C). A weaker, but significant, correlation of respiration with the $\mathrm{C}: \mathrm{N}$ of LOM or DOM (Fig 6D, Table 4) was also apparent as the $C: N$ ratio extended for $2 \mathrm{wk}$ beyond the peak in respiration.

\section{DISCUSSION}

In contrast to earlier studies (Kepkay et al. 1993, Niven et al. 1995), the 1995 bloom in Bedford Basin was weakly stratified due to low surface water temperatures and uniform salinities (Fig. 1C) associated with a relatively low freshwater input. This allowed the chlorophyll maximum at the height of the bloom (Fig. 1A) to develop to a depth of at least $20 \mathrm{~m}$ (Kepkay et al. 1997). As a result, the phytoplankton included in the chlorophyll maximum grew under relatively uniform conditions, i.e. at temperatures of 1 to $3^{\circ} \mathrm{C}$ and salinities of 30 to 31 (Fig. 1C), and at similar nutrient concentrations that decreased to about $1 \mu \mathrm{M}$ by the end of the bloom (Fig. 1B).

\section{Standing stock of organic carbon and nitrogen}

A complete standing stock of organic carbon (including both dissolved and particulate fractions) is essential for any real understanding of the dynamics of

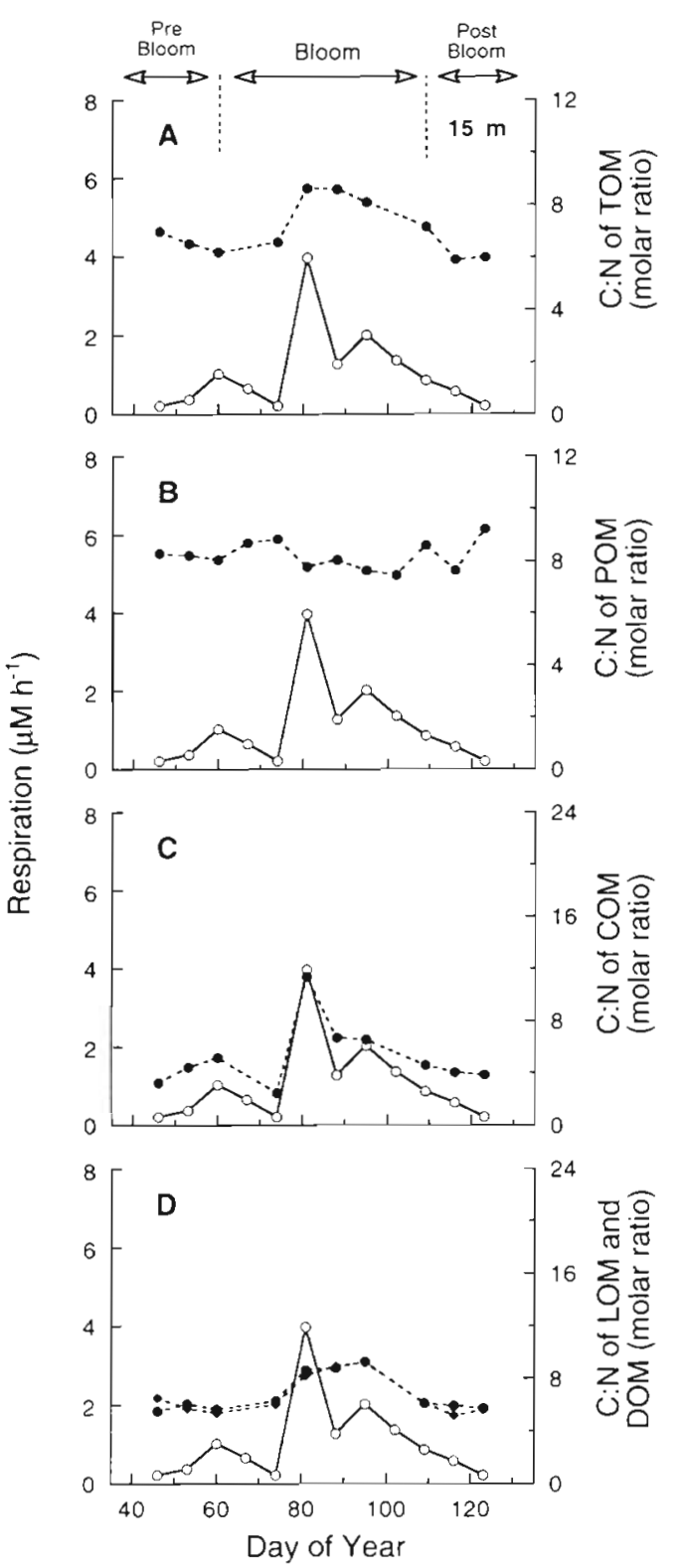

Fig. 6. Comparison of respiration (solid line) during the bloom at $15 \mathrm{~m}$ with the $(\therefore \mathrm{N}$ ratio (broken line) of (A) total organic matter, (B) particulate organic matter, (C) colloidal organic matter and (D) dissolved ( $\bullet$ ) or low molecular weight $(\bullet)$ organic matter. Pearson correlation coefficients ( $\mathrm{r}$ ) of the variation of respiration with $\mathrm{C}: \mathrm{N}$ ratio are summarized in Table 4 
Table 4. Correlation of respiration at $15 \mathrm{~m}$ with the $\mathrm{C}: \mathrm{N}$ of total organic matenal (TOM) and the C:N of organic material in the particulate (POM), colloidal (COM), dissolved (DOM) and low molecular weight (LOM) size fractions. Correlations are expressed in terms of the Pearson (linear) correlation coefficient $(\mathrm{r})$ and the significance $(\mathrm{p})$ associated with each correlation. For the sake of comparison, $p \leq 0.005$ is strongly significant, p between 0.005 and 0.1000 is weakly significant and $p \geq 0.100$ is not significant

\begin{tabular}{|lr|}
\hline $\begin{array}{l}\text { Organic carbon } \\
\text { size fraction }\end{array}$ & \multicolumn{1}{c|}{$\begin{array}{c}\text { Correlation } \\
\text { coefficient }(\mathrm{r})\end{array}$} \\
\hline TOM & $0.687(\mathrm{p} \leq 0.014)$ \\
POM & $-0.420(\mathrm{p} \leq 0.174)$ \\
COM & $0.972(\mathrm{p} \leq 0.005)$ \\
DOM & $0.625(\mathrm{p} \leq 0.030)$ \\
LOM & $0.751(\mathrm{p} \leq 0.012)$ \\
\hline
\end{tabular}

carbon cycling (Fig 2, Table 1). Most of the organic carbon produced during the bloom was released in the low molecular weight $(<1$ to $2 \mathrm{~nm}$ ) and colloidal (between 1 to $2 \mathrm{~nm}$ and $0.2 \mu \mathrm{m}$ ) size ranges (Kepkay et al. 1997). When these 2 size fractions were combined into a dissolved organic carbon (DOC) pool, they accounted for between 60 and $70 \%$ of the total organic carbon (TOC) produced during the bloom (Fig. 2). In contrast, particulate organic carbon (POC) was a relatively small fraction ( $<40 \%$ ) of TOC (Fig. 2A, Table 1 ). This leads to a perhaps obvious but important conclusion: bloom productivity may be drastically underestimated when defined solely from measurements of POC (one of the most commonly accepted indices of cell biomass and ocean productivity). In order to obtain a truly accurate definition of bloom productivity, the dissolved organic size fractions produced by the phytoplankton must be taken into account. It is also important to note that our colloidal size fractions were obtained using a $10 \mathrm{kD}$ cutoff rather than the more commonly employed $1 \mathrm{kD}$ (Buesseler et al. 1997). This means that we probably under-rather than over-estimated the contribution of colloids to the dissolved size fractions.

Throughout the bloom, the distribution of total organic nitrogen (TON) and its composite size fractions was more or less uniform (Fig. 3, Table 2), even though dissolved inorganic nitrogen (DIN) was near the concentration of TON before the bloom (Fig 3C) and decreased to low, but non-limiting concentrations $(\sim 1.0 \mu \mathrm{M} N)$ by the end of the bloom. This raises the question of where the DIN went during the bloom. The answer may lie in Cranford et al.'s (1995) data demonstrating that the nitrogen content of organic material in sediment traps increased as the bloom progressed. This increase in nitrogen may have been associated with the development of an active bacterial population in and on the aggregates that settled out into the traps. At this point, however, we camnot rule out the possibility that nitrogen may have also been removed by rapid recycling that would not have been detected with our 1 wk sampling interval

\section{Size-fractionated $\mathrm{C}: \mathrm{N}$ ratio}

When C:N ratios were derived from size-fractionated organic carbon and nitrogen (Fig. 4), it was clear that some process (or combination of processes) was driving the $\mathrm{C}: \mathrm{N}$ of total organic matter (TOM) up during the bloom (Fig. 4A.) and then returning the ratio to values similar to the $6.7: 1$ originally proposed by Redfield et al. (1963). The $C: N$ of particulate organic matter (POM) appeared to make little contribution to the change in C:N observed for TOM (Fig. 4). Instead, the major change in the $\mathrm{C}: \mathrm{N}$ ratio was in the dissolved size fraction - particularly in the colloidal size fraction (Fig. 4C), where $\mathrm{C}: \mathrm{N}$ reached a maximum of $20.5: 1$.

A high $\mathrm{C}: \mathrm{N}$ ratio for colloidal organic matter (COM) is consistent with the production of carbon-rich exopolymers (as polysaccharides) by leakage from actively growing phytoplankton early during a bloom (Kiørboe \& Hansen 1993, Kepkay et al. 1997) and leakage from senescent cells towards the end (Myklestad 1977, Ittekot et al. 1981, Smetacek 1985 and references therein, Eberlein \& Brockman 1986, Myklestad et al. 1989. Kepkay et al. 1993, 1997, Kiørboe \& Hansen 1993, Mopper et al. 1995). However, it is important to note that, even though polysaccharides are primarily found in the colloidal size fraction in surface waters (Benner et al. 1992. Amon \& Benner 1994), they can also be found as monomers in the low molecular weight size fraction (Benner et al. 1992). The production of carbon-rich monomers may well have been in operation during the bloom, where a high $\mathrm{C}: \mathrm{N}$ ratio of dissolved organic matter (DOM) appeared to be closely linked to an increase in the C:N of low molecular weight organic matter (LOM), which reached a maximum of 13.0:1 (Fig. 4D).

\section{Respiration and the size-fractionated $\mathrm{C}: \mathrm{N}$ ratio}

While our measurements of respiration varied by more than an order of magnitude (Figs. 5 \& 6), the mean respirations calculated from pre-bloom, bloom and post-bloom measurements at 5 and $15 \mathrm{~m}$ (Table 5) overlapped the range of values measured previously in Bedford Basin by Kepkay \& Johnson (1989). Our measurements were also well within the range of values (Table 5) established for respiration by coastal ocean communities (Smith \& Hollibaugh 1993 and references therein). The respiration values reviewed and included in this yearly average were calculated either from car- 
Table 5. Comparison of mean, short-term respiration measured in Bedford Basin with previous measurements of respiration in the Basin and the mean annual respiration calculated for 22 marine coastal communities

\begin{tabular}{|c|c|c|c|c|}
\hline \multirow[t]{2}{*}{ Coastal system } & \multicolumn{3}{|c|}{$\begin{array}{l}\text { Respiration } \\
\left(\mathrm{g} \subset \mathrm{m}^{-2} \mathrm{yr}^{-1}\right)\end{array}$} & \multirow[t]{2}{*}{ Source } \\
\hline & Mean & $\mathrm{SD}$ & Range & \\
\hline Bedford Basin & 141 & 149 & $23-658$ & This study \\
\hline Bedford Basin & 132 & 126 & $11-211$ & Kepkay \& Johnson (1989) \\
\hline Coastal communities & 316 & 256 & $34-1122$ & Smith \& Hollibaugh (1993) \\
\hline
\end{tabular}

trafiltration cartridges to define the lower limit of the colloid size range would tend to under-rather than over-estimate the contribution of colloids to the $\mathrm{C}: \mathrm{N}$ ratio of the total standing stock.

Kepkay et al. (1997) have shown that more colloidal organic carbon was produced at 5 than at $15 \mathrm{~m}$ presumably because phytoplankton production was attenuated at

bon-nitrogen-phosphorus stoichiometry (see Smith et al. 1991) or from net oxygen flux (see Hoppema 1991a, b). Our results were obtained from short-term incubations that were $<1.5 \mathrm{~h}$ in duration. The overall agreement between results obtained with such different techniques indicates that short-term, direct measurements may provide an independent means for assessing the accuracy of respiration estimates in models of coastal ocean heterotrophy (Smith \& Mackenzie 1987. Smith \& Hollibaugh 1993).

At this point, however, the question remains: what process was driving the C:N of TOM back to Redfield values during the bloom? The data in Figs. $5 \& 6$ (and the correlations in Tables $3 \& 4$ ) suggest that respiration may have regulated the $C: N$ ratio of TOM, mineralizing the excess organic carbon produced as phytoplankton exudates in the dissolved size fraction. In effect, respiration returmed the $\mathrm{C}: \mathrm{N}$ ratio to values (Figs. 5A \& $6 \mathrm{~A}$ ) that were similar to the ratio of $6.7: 1$ proposed by Redfield et al. (1963) for the production and degradation of marine organic matter. This regulation of the $\mathrm{C}: \mathrm{N}$ ratio of TOM by respiration had no apparent effect on the C:N of POM (Figs. 5B \& 6B) which remained relatively uniform, but greater than 6.7:1 Higher-than-Redfield ratios in the particulate fraction have already been observed in phytoplankton cultures (Goldman et al. 1979 and references therein, Dortch 1982 and references therein) and may also indicate that carbon-rich exudates were closely associated with cells. However, the significant positive correlation of respiration with the C:N of COM (Figs. 5C \& 6C, Tables $3 \& 4$ ) suggests that at least some of the exudates released as larger colloids were mineralized within the 1 wk sampling interval. In addition, very little of the DIN involved in primary production and respiration (Fig. 3C) appeared to accumulate in the PON, DON or CON pools (Fig. 3A, B) This means that, even though colloid-sized organic exudates may be only 16 to $22 \%$ of DOC during blooms (Kepkay et al. 1993, 1997, Niven et al. 1995) and <12\% of TOC (Fig. 2, Table 1), they could still have a pronounced effect on the C:N of TOM during periods of high productivity. It should also be stressed that our results are conservative in their estimation of the amount of colloids produced. The utilization of $10 \mathrm{kD}$ rather than $1 \mathrm{kD}$ ul- the greater depth. However, lower respiration at $15 \mathrm{~m}$ was still closely correlated with the C:N of CON (Fig. $6 \mathrm{C}$, Table 4), even though the correlation of respiration with the C:N of TOM was weaker at 15 than at $5 \mathrm{~m}$ (Fig. 6A, Table 4). This weaker correlation was probably related to the fact that the elevated C:N of LOM and DOM extended for $2 \mathrm{wk}$ after the peak in respiration (Fig 6D). The origin of these broad, low peaks in the $C: N$ ratio remains unknown, but could be related to the long-term degradation of POM to generate LOM at lower light in deeper water.

\section{Respiration, the microbial loop and the carbon/nitrogen budget}

To our knowledge, the results from Bedford Basin are the first direct demonstration that respiration can regulate the $\mathrm{C}: \mathrm{N}$ ratio of total (rather than particulate) organic matter in surface waters. Even though our measurements are in agreement with Smith \& Hollibaugh's (1993) yearly average for respiration in coastal systems (Table 5), they are not in agreement with a widely held assumption that the microbial loop (Azam et al. 1983) operates under the constraint that POM must first be broken down to DOM. before it can be respired to $\mathrm{CO}_{2}$ and released as inorganic nitrogen. During the bloom, the microbial loop appeared to be short-circuited by the rapid respiration of carbon-rich phytoplankton exudates that were not necessarily produced by decomposition. The time scale of this respiratory response was within our 1 wk sampling interval. and agrees with Smith \& MacKenzie's (1987) estimate for the response time of estuaries and coastal waters. In addition, the respiratory response appeared to remove organic carbon and regulate the C:N of TOM (Fig. 5), returning the ratio to values similar to that predicted by Redfield stoichiometry (6.7:1).

Given the fact that respiration (as a rate) was correlated only with the bulk concentration (rather than the rate of production) of organic carbon in the various size fractions, it is important to stress that the correlations cannot be used to quantify the effect of carbon degradation on the bloom's carbon budget. The difficulty of 
establishing an organic carbon budget for the bloom is further highlighted by the apparent conflict between the POC increase calculated from chl a concentrations at the height of the bloom (Fig. 1) - approximately $50 \mu \mathrm{M} C$ on Day 88 using Li et al.'s (1993) C:chl a ratio of $40: 1$ - and the maximum increase in POC that was actually recorded (about $10 \mu \mathrm{M} \mathrm{C}$ in Fig. 2). This conflict between low POC concentrations when phytoplankton productivity (as defined by chl a) was at its height can be resolved by taking sedimentation into account. There were strong peaks of carbon flux into traps 1 wk before and 1 wk after the chl a maximum (Niven et al. 1997) This leads to an important conclusion: respiration cannot be considered in isolation in its effect on the organic carbon budget. The rapid sedimentation of organic material is also important (Niven at al. 1997). This means that it will probably not be possible to establish a carbon budget for surface waters during a coastal bloom without coincident measurements of primary production, respiration and sedimentation over exactly the same time intervals.

\section{Organic size fractions and biota involved in respiration}

We cannot be sure that only colloid-sized fractions of DOM were respired, but our results are in agreement with Santschi et al.'s (1995) finding that colloids are the 'young' fraction of DOM that is capable of being rapidly turned over by microbial activity. Even so, it cannot be denied that LOM contributed to the high $\mathrm{C}: \mathrm{N}$ of TOM (Figs. 4, $5 \& 6$ ). In addition, the relatively high (but uniform) C:N of POM (Figs. 4, $5 \& 6$ ) suggests that high-carbon exudates may have been closely associated with phytoplankton cells or aggregated into transparent exopolymer particles (Alldredge et al. 1993, Passow et al. 1994) throughout the bloom (Niven et al. 1997). We do not know if this high-carbon, particulate material was eventually made available for respiration by the whole community, but it is clear from previous work in Bedford Basin and the open ocean (Kepkay \& Johnson 1989) that colloid aggregation can trigger short-lived bursts of intense bacterial respiration.

We also cannot be sure which organisms were responsible for such a strong respiratory response to high productivity during the bloom, but respiration was positively correlated with bacterial number (Jellett et al. unpubl.). When combined with previous observations (Kepkay et al. 1993, Niven et al. 1995) that zooplankton are generally absent during blooms in Bedford Basin, these data suggest that bacteria may make a major contribution to respiration. However, the bacteria were certainly not the only micro-organisms involved. The protozoa (Kepkay \& Johnson 1989) and phytoplankton (Langdon et al. 1997) are also important components of total community respiration.

\section{Summary}

Even though we cannot pinpoint which microbiota or size fractions of organic carbon made the greatest contributions to community respiration, we can draw 3 conclusions from the Basin bloom that may be applicable to coastal ocean systems as a whole:

(1) Particulate organic carbon (POC), which is one of the most widely accepted measures of plankton biomass, is a relatively small fraction of the total standing stock of organic carbon (Fig. 2). The dissolved organic carbon (DOC) associated with the production of phytoplankton exudates is the predominant pool of organic carbon.

(2) The C:N of particulate organic material (POM) is not an accurate index of the $\mathrm{C}: \mathrm{N}$ of the total standing stock of organic material (TOM). Instead, variations in the $\mathrm{C}$ : $N$ of colloidal organic material (COM) and low molecular weight organic material (LOM) are prime regulators of the $\mathrm{C}: \mathrm{N}$ of the total standing stock (Fig. 4)

(3) Microbial respiration is an important regulator of the C:N of TOM during periods of high productivity (such as those encountered during the bloom) This respiratory regulation of the $\mathrm{C}: \mathrm{N}$ ratio is focused primarily on the degradation of carbon-rich phytoplankton exudates in the colloidal size fraction (Figs. $5 \& 6$ ) Given the extreme metabolic flexibility of the bacteria, this respiration of colloidal organic carbon $(\mathrm{COC})$ by the microbial community may short-circuit the microbial loop and combine with the sedimentation of aggregates to remove the excess carbon produced as exudates.

All three of these conclusions should be taken into account if the net heterotrophy of a coastal system (Smith \& MacKenzie 1987. Smith \& Hollibaugh 1993) is to be accurately defined.

Acknowledgements. We thank Wenhao Chen for organic nitrogen measurements and Jay Bugden, Peter Cranford, Ryan O'Meara and Stacey Denny for their help during the collection and analysis of samples. We also thank Oswaldo Ulloa for pointing out the necessity for direct (as well as stoichiometric) estimates of respiration, the stafi of the Defense Research Establishment Atlantic (DREA) for use of their acoustic facility, and Fred Lindemeyer (Environment Canada) for data on discharge of the Sackville River The work was supported by the ocean productivity sector of the Department of Fisheries and Oceans, the Canadian Panel of Energy R\&D (PERD) and the ocean climate component of the Canadian Green Plan 


\section{LITERATURE CITED}

Alldredge AL, Passow U, Logan BE (1993) The abundance and significance of a class of large transparent organic particles in the ocean. Deep Sea Res 40:1131-1140

Amon RMW, Benner R (1994) Rapid cycling of high-molecular-weight dissolved organic matter in the ocean. Nature 369:549-552

Azam F, Fenchel T, Field JG, Gray JS, Meyer-Reil LA, Thingstad $F$ (1983) The ecological role of water-column microbes in the sea. Mar Ecol Prog Ser 10:257-263

Benner R, Pakulski JD, McCarthy M, Hedges JI, Hatcher PG (1.992) Bulk characteristics of dissolved organic matter in the ocean. Science 255:1561-1564

Biddanda B, Benner R (1997) Carbon, nitrogen and carbohydrate flux during the production of particulate and dissolved organic matter by marine phytoplankton. Limnol Oceanogr (in press)

Buesseler KO, Bauer JE, Chen RF, Eglinton Tl, Gustafsson O, Landing W, Mopper $\mathrm{K}$, Moran SB, Santschi PH, Vernon Clark R, Wells ML (1997) Sampling marine colloids using cross-flow filtration: overview and results from an intercomparison study. Mar Chem (in press)

Carlson CA, Ducklow HW, Michaels AF (1994) Annual flux of dissolved organic carbon from the euphotic zone in the northwestern Sargasso Sea. Nature 371:405-408

Chen W, Wangersky PJ (1993) A high temperature catalytic oxidation method for the determination of marine dissolved organic carbon and its comparison with the ultraviolet photo-oxidation method. Mar Chem 42:95-106

Cranford PJ, Vass WP, Reimer DP (1995) HABITRAP: a new in situ technique using shellfish for monitoring biological effects of anthropogenic and natural changes in the coastal environment. Proc 1995 Can Coast Conf 1:171-185

Dortch Q (1982) Effect of growth condition on accumulation of internal nitrate, ammonium, amino acids and protein in three marme diatoms. J Exp Mar Biol Ecol 16:243-264

Duursma E (1961) Dissolved organic carbon, nitrogen and phosphorus in the sea. Neth J Sea Res 1:1-148

Eberlein K, Brockman UH (1986) Development of particulate and dissolved carbohydrates in parallel enclosure experiments with monocultures of Thalassiosira rotula. Mar Ecol Prog Ser 32:133-138

Goldman JC, Hansell DA, Peavey DG (1979) Growth rate influence on the chemical composition of phytoplankton in oceanic waters. Nature 279:210-215

Grasshoff $K$, Johanssen $H$ (1972) A new sensitive and direct method for the automatic determination of ammonia in sea water. J Cons Perm Int Explor Mer 34:516-521

Gregory D, Petne B, Jordan F, Langille P (1993) Oceanographic, geographic and hydrological parameters of Scotia-Fundy and southern Gulf of St. Lawrence inlets. Can Tech Rep Hydrogr Ocean Sci 143:1-248

Hansell DA (1993) Results and observations from the mea surement of DOC and DON in seawater using a high-temperature catalytic oxidation technique. Mar Chem 41 $195-202$

Hansell DA, Williams PM, Ward BB (1993) Measurements of DOC and DON in the southern California Bight using oxidation by high temperature combustion. Deep Sea Res 40 : $219-234$

Holm-Hansen O, Lorenzen CJ, Holmes RW, Strickland JDH (1965) Fluorometric determination of chlorophy]l. J Cons Perm Int Explor Mer 30:3-1.5

Hoppema JMJ (1991a) The oxygen budget of the western Wadden Sea, the Netherlands. Estuar Coast Shelf Sci 32: 483-502
Hoppema JMJ (1991b) The seasonal behaviour of carbon dioxide and oxygen in the coastal North Sea along the Netherlands. Neth J Sea Res 28:167-179

Ittekot V, Brockman U, Degens ET (1981) Dissolved free and combined carbohydrates during a phytoplankton bloom in the northern North Sea. Mar Ecol Prog Ser 4:299-305

Karl DM, Tien G, Dore J, Winn CD (1993) Total dissolved nitrogen and phosphorus concentrations at US-JGOFS station ALOHA: Redfield reconciliation. Mar Chem 41 203-208

Kepkity PE (1994) Particle aggregation and the biological reactivity of colloids. Mar Ecol Prog Ser 109:293-304

Kepkay PE, Johnson BD (1989) Coayulation on bubbles allows the microbial respiration of oceanic dissolved organic carbon. Nature 385:63-6j

Kepkay PE, Niven SEH, Jellett JF (1997) Colloidal organic carbon and phytoplankton speciation during a coastal bloom. J Plankton Res (in press)

Kepkay PE, Niven SEH, Milligan TG (1993) Low molecular weight and colloidal DOC production during a phytoplankton bloom. Mar Ecol Prog Ser 100:233-244

Kiorboe T, Hansen JLS (1993) Phytoplankton aggregate formation: observations of patterns and mechanisms of cell sticking and the significance of exopolymeric material. J Plankton Res 15:993-1018

Koike I. Tupas L (1993) Total dissolved nutrogen in the northern North Pacific assessed by a high-temperature combustion method. Mar Chem 41:209-214

Langdon C, Marra J, Knudson C (1997) Measurements of net and gross $\mathrm{O}_{2}$ production, dark $\mathrm{O}_{2}$ respiration and ${ }^{14} \mathrm{C}$ assimilation at the ML-ML site $\left(59^{\circ} \mathrm{N} 21^{\circ} \mathrm{W}\right)$ in the northeast Atlantic Ocean. J Geophys Res (in press)

Li WKW, Dickie PM. Harrison WG, Irwin BD (1993) Biomass and the production of bacteria and phytoplankton during the spring bloom in the western North Atlantic Ocean. Deep Sea Res 40:307-327

Mopper K, Zhou J, Ramana KS, Passow U, Dam HG, Drapeau DT (1995) Role of surface-active carbohydrates in the flocculation of a diatom bloom in a mesocosm. Deep Sea Res II $42: 47-74$

Myklestad S (1977) Production of carbohydrates by marine planktonic diatoms. II. Influence of N/P ratio in the growth medium on the assimilation ratio, growth rate and production of cellular and extracellular carbohydrates by Chaetoceros affinis var. Willei (Gran.) Hustedt and Skeletonema costatum (Grev.) Cleve. J Exp Mar Bıl Ecol 29:161-179

Myklestad S, Holm-Hansen O, Varum KM, Volcani BE (1989) Rate of release of extracellular amino acids and carbohydrates from the marine diatom Chaetoceros affinis. J Plankton Res 11:763-.773

Niven SEH, Kepkay PE, Boraie A (1995) Colloidal organic carbon and collordal ${ }^{234}$ Th dynamics during a coastal phytoplankton bloom. Deep Sea Res II 42:257-273

Niven SEH. Kepkay PE, Bugden JBC (1997) The role of TEP in ${ }^{234}$ Th scavenging dunng a coastal diatom bloom. Radıoprotection (in press)

Norrman B, Zweifel. CS, Hopkinson CS, Fry B (1995) Production and utilization of dissolved orgarsic carbon during an experimental diatom bloom. Limnol Oceanogr 40:898-907

Passow U, Alldredge AL, Logan BE (1994) The role of particulate carbohydrate exudates in the flocculation of diatom blooms. Deep Sea Res 41:335-357

Petrie B, Yeats P (1990) Simple models of the circulation, dissolved metals, suspended solids and nutrients in Halifax Harbour. Water Pollut Res J Can 25:325-349

Redfield AC, Ketchum BH, Richards FA (1963) The influence 
of organisms on the composition of seawater In: Hill MN (ed) The sea, ideas and observations on progress in the study of the seas, Vol 2. Interscience, New York, p 26-77

Samuel S, Shah NM, Fogg GE (1971) Liberation of extracellular products of phytoplankton by tropical phytoplankton. J Mar Biol Assoc UK 51:793-798

Santschi PH, Guo L, Baskaran M, Trumbore S, Southon J, Bianchi TS, Honeyman B, Cifuentes L (1995) Isotopic evidence for the contemporary origin of high-molecular weight organic matter in oceanic environments. Geochim Cosmochim Acta 59(3):625-631

Smetacek VS (1985) Role of sinkıng in diatom life-hıstory cycles: ecological, evolutionary and geological significance. Mar Biol 84:239-251

Smith DC, Steward GF, Long RA. Azam F (1995) Bacteral mediation of carbon fluxes during a diatom bloom in a mesocosm. Deep Sea Res II 42:75-97

Smith SV, Mackenzie FT (1987) The ocean as a net hetero-

This article was submitted to the editor trophic system: implications from the carbon biogeochemical cycle. Global Biogeochem Cycles 1:195-215

Smith SV, Hollibaugh JT, Dollar SJ, Vink S (1991) Tomales Bay metabolism: C-N-P stoichiometry and ecosystem heterotrophy at the land-sea interface. Estuar Coast Shelf Sci 33:223-257

Smith SV, Hollibaugh JT (1993) Coastal metabolism and the oceanic carbon balance. Rev Geophys 31:75-89

Thomas JP (1971) Release of dissolved organic matter from natural populations of marine phytoplankton. Mar Biol 18: $311-323$

Tupas LM, Popp BN, Karl DM (1994) Dissolved organic carbon in oligotrophic waters: experiments on sample preservation, storage and analysis. Mar Chem 45: $207-216$

Walsh TW (1989) Total dissolved nitrogen in seawater: a new high-temperature combustion method and a comparison with photo-oxidation. Mar Chem 26:295-311

Manuscript first received: February 8,1996

Revised version accepted: January 31, 1997 